\title{
PENGOLAHAN KELAPA PARUT KERING (DESICCATED COCONUT) DI PT. KOKONAKO INDONESIA PULAU PALAS INDRAGIRI HILIR RIAU
}

\author{
Agus Nuroso, S.TP*), dan Yusi Syafarina**) \\ ${ }^{*}$ Dosen Teknologi Pangan Faperta UNISI \\ **) Alumni Politeknik Pertanian Tembilahan \\ ponyomr@yahoo.co.id
}

\begin{abstract}
Abstrak
PT. KOKONAKO INDONESIA Pulau Palas adalah perusahaan yang bergerak di bidang industri pertanian salah satu produknya adalah kelapa parut kering (Desiccated Coconut). Untuk menghasilkan mutu yang baik dari kelapa parut kering perlu mengetahui proses pengolahan secara tepat. Proses Pengolahan kelapa parut kering di PT.Kokonako Indonesia adalah sebagai berikut penerimaan bahan baku, pengupasan tempurung, Pengupasan kulit ari, pencucian, penyortiran, pemarutan, sterilisasi, pengeringan, pengemasan, yang di proses dengan tingkat ke higienisan yang tinggi.
\end{abstract}

\section{PENDAHULUAN}

Kelapa adalah salah satu komoditi perkebunan yang penting bagi Indonesia disamping kakao, kopi, lada dan vanili. Komoditi ini telah lama dikenal dan sangat berperan bagi kehidupan bangsa Indonesia baik ditinjau dari aspek ekonomi maupun aspek sosial budaya (palungkun, 2003).

Riau merupakan salah satu sentral produksi kelapa di Indonesia, khususnya Kabupaten Indragiri Hilir dimana hampir seluruh masyarakatnya hidup sebagai petani kelapa. Luas areal perkebunan kelapa di Kabupaten Indragiri Hilir mencapai 408.824 ha dengan jumlah produksi kelapa sebanyak 8.555.667 butir per hari yang tersebar di seluruh kecamatan. Hal ini merupakan potensi yang sangat besar untuk mengembangkan sektor industri yang berbasis usaha sektor pertanian dan perkebunan.
Adanya potensi yang sangat besar ini harus dimanfaatkan agar tingkat pendapatan para petani kelapa lebih meningkat. Namun, sampai saat ini masih ada beberapa kendala yang menyebabkan pendapatan para petani kelapa masih rendah. Dimana kendalanya adalah pengolahan kelapa masih bersifat tradisional dan kurangnya industri pengolahan kelapa. Masalah ini menyebabkan petani tidak mempunyai alternatif lain untuk memasarkan hasil kelapanya. Padahal dari komoditi kelapa ini dapat diperoleh beranekaragam olahan kelapa yang mempunyai nilai ekonomis dan prospek pasar yang baik. Salah satu aneka olahan itu adalah kelapa parut kering (Desiccated Coconut). Kelapa parut kering adalah daging buah kelapa yang dihaluskan, dikeringkan dan diproses secara higienis untuk bahan baku makanan. Tujuan kelapa diolah menjadi kelapa parut kering adalah untuk mengurangi kerugian usaha yaitu dilakukan 
pengawetan dengan cara mengurangi kadar airnya (Palungkun, 2003).

\section{PEMBAHASAN}

Kelapa parut kering adalah kelapa parut yang dihasilkan dari daging buah kelapa putih melalui tahapan proses pemarutan dengan ukuran yang sesuai dengan spesifikasinya, dilanjutkan dengan proses sterilisasi, pengeringan, pengayakan dan pengemasan yang diproses dengan cara atau kondisi higienis yang tinggi.

Tabel 1. Komposisi Kimia Kelapa Parut Kering

\begin{tabular}{|c|c|}
\hline Komponen & Jumlah (\%) \\
\hline Air & 2,0 \\
Lemak & 67,50 \\
Karbohidrat & 5,9 \\
Protein & 9,3 \\
Abu & 2,4 \\
Serat & 3,9 \\
Pentosan & 8,9 \\
\hline
\end{tabular}

Sumber : Ketaren dan Djatmiko, 1985

Kandungan unsur kimia yang terbanyak pada kelapa parut kering adalah lemak, protein dan pentosan. Kadar lemak dari kelapa parut kering maksimal adalah 68\%. Besarnya kadar lemak akan berpengaruh pada besarnya asam lemak bebas dan angka ketengikan selama proses penyimpanan. Sedangkan batas maksimum asam lemak bebas (FFA) dari kelapa parut kering adalah $0,3 \%$ terhitung sebagai asam laurat. Asam lemak bebas yang terlalu tinggi akan memperpendek umur simpan dari kelapa parut kering.

\section{Pengolahan Kelapa Parut Kering (Desiccated Coconut)}

Proses pengolahan kelapa parut kering di PT. Kokonako Indonesia Pulau Palas Indragiri Hilir Riau adalah :

1. Persiapan Bahan Baku

Sebelum diterima di pabrik, kelapa harus diseleksi. Penyeleksian bahan baku yang dibeli dari petani kelapa untuk pengolahan Desiccated
Coconut (DC) harus kelapa tua yang bermutu A yaitu untuk diameter A1 (> 13,5 cm), A2 $(12,5 \mathrm{~cm} \mathrm{-} \mathrm{<} \mathrm{13,5}$ $\mathrm{cm})$, A3 $(11,5 \mathrm{~cm}-<12,5 \mathrm{~cm})$. Kelapa tua yang bermutu B yang diameternya $(<10,00 \mathrm{~cm})$, kelapa tidak berkecambah, tempurung tidak pecah, kematangan cukup, batok kelapa kehitam-hitaman dan tidak menerima kelapa yang berjambul.

2. Sortasi kelapa

Penyortiran kelapa untuk pengolahan DC bertujuan untuk memilih kelapa yang sesuai dengan spesifikasi agar tidak mempengaruhi kualitas DC. Kelapa bulat untuk pengolahan DC adalah kelapa segar, tidak berkecambah, tempurung tidak pecah, kematangan cukup dan warna batok kelapa coklat kehitam-hitaman. Bahan baku yang sesuai dengan spesifikasi kemudian dimasukkan ke dalam keranjang shaller dan bahan baku yang tidak sesuai dengan spesifikasi 
digunakan untuk bahan baku pengolahan minyak kelapa.

3. Pengupasan Tempurung

Kelapa bulat dari keranjang shaller di bawa ke tempat pemecahan tempurung, kelapa bulat dipecah tempurungnya dengan menggunakan mesin shaller atau pemisah tempurung tanpa memecah daging buahnya, sebab daging buah kelapa yang pecah akan mengganggu proses berikutnya yaitu pengupasan kulit ari. Tujuan pengupasan tempurung agar tidak mempersulit proses pengupasan kulit ari.

4. Pengupasan Kulit Ari

Pengupasan kulit ari pada kelapa dilakukan dengan menggunakan pisau khusus yaitu pisau paring. Tujuan dari pengupasan kulit ari adalah untuk mendapatkan daging kelapa putih.

Ukuran ketebalan daging kelapa putih yaitu $8-12 \mathrm{~mm}$ dan ketebalan pengupasan kulit ari maksimal 1,60 $\mathrm{mm}$ dan dalam proses pengupasan kulit ari 12-15\% daging buah ikut terkupas bersamaan kulit ari. Ketebalan kulit ari hasil pengupasan diukur dengan menggunakan alat ukur mikrometer (jangka sorong), setelah dikupas daging buah dibelah dua untuk dibuang air kelapanya, sedangkan hasil kupasan kulit ari ditampung untuk diolah menjadi minyak kelapa.

5. Pencucian dan Penyimpanan

Pencucian daging kelapa dilakukan dengan menggunakan air bersih yang di supply dari water treatment (WT), lalu air dari WT dialirkan di atas belt conveyer untuk mempermudah proses pencucian, kemudian dilakukan penyortiran sisa kulit ari yang belum terkupas, tumbung tempurung, serabut kelapa, kelapa berlendir dan benda asing lainnya. Pencucian daging kelapa bertujuan untuk membersihkan daging kelapa dari kotoran kelapa itu sendiri, benda asing dan untuk mencegah terjadinya perubahan warna, setelah itu daging kelapa dimasukkan ke dalam transfer tank. Transfer tank adalah tangki penyimpanan sementara, tujuan daging buah kelapa disimpan di transfer tank adalah untuk menyimpan sementara material sebelum masuk ke grinder dan penyediaan bahan baku dapat tersuplay pada waktu produksi. Daging kelapa disimpan di dalam transfer tank selama 1 jam, kapasitas penyimpanan daging kelapa di dalam transfer tank sebanyak 6 ton. Transfer tank terdiri dari 3 sekat, tiap sekatnya memiliki kapasitas 2 ton.

6. Penyortiran Daging kelapa

Daging kelapa dari transfer tank lalu di bawa ke belt conveyer untuk dilakukan proses penyortiran tahap akhir. Daging kelapa yang tidak sesuai spesifikasi yang berasal dari area packing dan ruang penyimpanan juga disortir. Daging kelapa yang sudah disortir dipindahkan melalui screw conveyer menuju mesin grinder untuk proses selanjutnya yaitu proses pemarutan.

7. Pemarutan

Proses pemarutan dilakukan dengan menggunakan mesin grinder. Tujuan dari pemarutan adalah untuk mendapatkan DC dengan ukuran parutan yang berbeda-beda. Fungsi mesin grinder adalah menghancurkan/memperkecil ukuran produk sesuai spesifikasi 
ukuran yaitu medium $(2,90 \mathrm{~mm})$, fine $(1,40 \mathrm{~mm})$, extra fine $(0,60$ $\mathrm{mm})$ diinginkan. Agar dapat mengetahui hasil parutan untuk membedakan ukuran medium dan fine maka dapat dilakukan dengan metode water test yaitu :
a. Setelah mesin grinder dioperasikan, ambil sampel kelapa parut.
b. Taburkan sampel ke dalam saringan stainless dibawah kran air jernih yang mengalir.
c. Analisa sampel secara visual kemudian tentukan sesuai spesifikasi medium dan fine.

8. Penyemprotan $\mathrm{SO}_{2}$

Penyemprotan Sodium Metabisulfit $\left(\mathrm{SO}_{2}\right)$ dilakukan sesuai dengan permintaan buyer, dosisnya 30-50 ppm max, perbandingan $\mathrm{SO}_{2}$ dengan daging kelapa yaitu $3 \mathrm{~kg}$ : $6.000 \quad \mathrm{~kg} . \quad \mathrm{SO}_{2} \quad$ langsung disemprotkan pada bahan baku, tujuan penambahan larutan ini sebagai pemutih pada DC. Dampak yang terjadi bila dosis $\mathrm{SO}_{2}$ berlebihan bisa menyebabkan kemandulan dan pengaruh yang terjadi pada DC, warna DC menjadi suram dan dampak yang terjadi bila dosis $\mathrm{SO}_{2}$ kurang yaitu warna putih pada DC tidak maksimal.

9. Sterilisasi

Proses sterilisasi dilakukan dengan menggunakan steam dari boiler pada suhu $100^{\circ} \mathrm{C}-120^{\circ} \mathrm{C}$ selama 10 15 menit dengan tujuan menonaktifkan mikroorganisme pada parutan daging kelapa putih.

10. Drying

Proses drying/pengeringan adalah salah satu cara untuk menjaga agar produk dapat tahan lama. Prinsip dari pengeringan adalah mengurangi kadar air dalam bahan dengan cara pemanasan sehingga didapatkan DC dengan kadar air 1,8 \% - 2,9\% dan mikroorganisme tidak dapat tumbuh lagi pada bahan tersebut. Pengeringan pada DC menggunakan mesin dryer.

Proses pengeringan pada dyer melalui tiga tahap yaitu stage A, Stage B dan stage $\mathrm{C}$ dimana setiap stagenya diberi temperatur yang berbeda-beda yaitu stage A : $110^{\circ} \mathrm{C}-135^{\circ} \mathrm{C}$ untuk mencapai kadar air $54 \%$, stage $\mathrm{B}: 80^{\circ} \mathrm{C}-120^{\circ} \mathrm{C}$ untuk mencapai kadar air $30 \%$, stage $\mathrm{C}: 70^{\circ} \mathrm{C}-100^{\circ} \mathrm{C}$ untuk mencapai kadar air $1,8 \%$. Tujuannya agar DC tidak gosong yang menyebabkan warna menjadi coklat kehitam-hitaman. Lama pengeringan yaitu 20 menit.

11. Pengayakan

Pengayakan merupakan proses pemisahan DC mulai dari ukuran besar sampai terkecil. Tujuannya untuk mendapatkan ukuran yang diinginkan seperti medium, fine dan extra fine.Untuk pengayakan menggunakan mesin rotex.

12. Penyortiran

Penyortiran bertujuan untuk menyortir DC, yang dikontrol adalah kulit ari dan kotoran-kotoran lainnya. Untuk kotoran logam dipasang batangan magnet pada ujung aliran agar bisa menangkap logam tersebut.

13. Penyimpanan sementara

Penyimpanan produk sementara adalah hopper tank sebelum di packing. Lama penyimpanan 30 menit. Penyimpanan sementara bertujuan untuk menstabilkan proses pengisian produk di dalam brown bag. 
14. Pengemasan

Pada tahap ini produk di inspeksi oleh badan quality sebelum di packing. Inspeksi bertujuan untuk menyesuaikan standar seperti warna harus putih, tidak lembab, bebas dari logam dan benda asing lainnya. Bila semuanya telah sesuai dengan standar maka produk layak untuk di packing. Setelah produk di packing, produk akan ditimbang. Penimbangan ini berfungsi untuk mengukur berat produk dalam bag. Berat produk dalam kemasan : 100 lbs (45,36 kg), $55 \mathrm{lbs}(25 \mathrm{~kg}), 50 \mathrm{lbs}$ $(22,68 \mathrm{~kg}), 25 \mathrm{lbs}(11,34 \mathrm{~kg})$ dan 10 lbs $(4,536 \mathrm{~kg})$.

Pengemasan terdiri dari pengemasan primer yang berupa plastik polyethylene dan pengemasan skunder berupa brown bag di beri label/kode. Contoh : 10 - AP - F - 0000

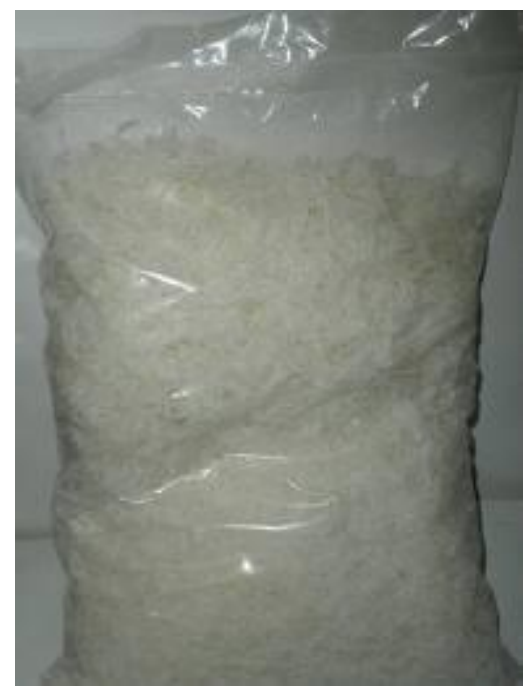

Keterangan :

$10=$ tahun 2010

$\mathrm{AP}=$ bulan april

$\mathrm{F} \quad=$ Ukuran Fine

$00=$ no. urut bag/ bulan produksi

\section{Penyimpanan}

DC yang sudah dikemas disimpan dalam ruangan yang bersih, kering dan berventilasi udara baik dan tidak terkena sinar matahari langsung. Hal ini bertujuan untuk menghindari dari proses oksidasi agar DC tidak berubah warna dan berbau tengik. Simpan pada suhu antara $25-35^{\circ} \mathrm{C}$ dengan kelembaban (RH) $\max 75 \%$. Jika kondisi penyimpanan baik, maka DC tahan disimpan selama 1-2 bulan tanpa berbau tengik, berubah warna.

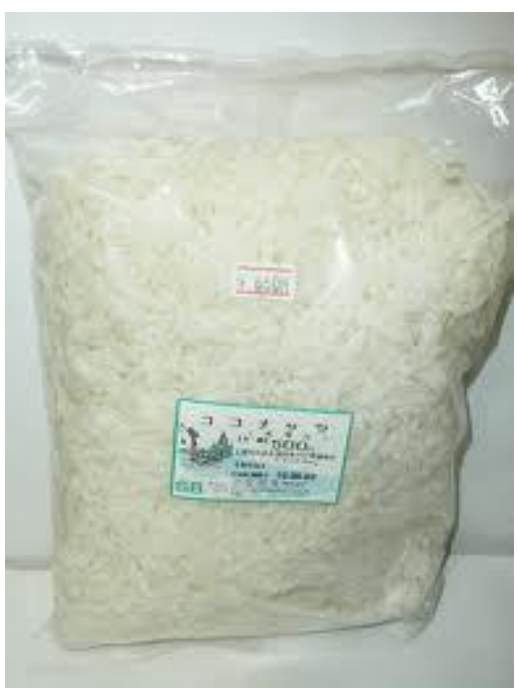

Gambar 1. Gambar kelapa parut kering 
BAGAN ALIR PENGOLAHAN KELAPA PARUT KERING

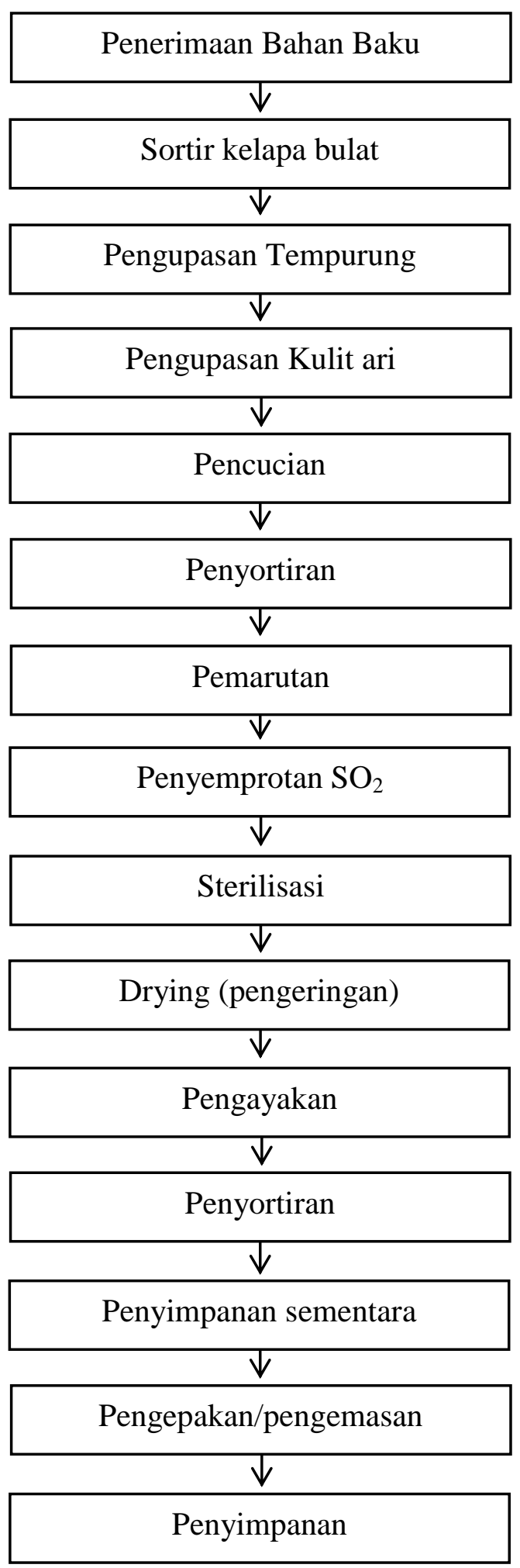

Sumber : PT. Kokonako Indonesia, 2010 


\section{KESIMPULAN}

a. Kelapa bulat yang diterima di PT.Kokonako Indonesia untuk diolah menjadi kelapa parut kering adalah segar, tempurung tidak pecah, tidak berlendir dan tidak berbau tengik.

b. PT. Kokonako Indonesia mengolah kelapa parut kering dengan 3 jenis standar ukuran parutan yaitu ukuran medium, fine dan extra fine.

c. Kelapa parut kering di PT. Kokonako Indonesia dihasilkan dari daging kelapa putih melalui tahapan proses yaitu penerimaan bahan baku, pengupasan tempurung, Pengupasan kulit ari, pencucian, penyortiran, pemarutan, sterilisasi, pengeringan, pengemasan, yang di proses dengan tingkat ke higienisan yang tinggi.

\section{DAFTAR PUSTAKA}

Anonimus. 2008. Panduan Kerja Pengolahan Kelapa Parut Kering. PT. Kokonako Indonesia Riau

Kataren, S dan B. Djatmika. 1985. Daya Guna Hasil Kelapa Agroindustri. Bogor.
Kataren, S. 2008. Minyak dan Lemak Pangan. Universitas Indonesia (UI-Press) Jakarta.

Margono T, D. Suryati, S. Hartinah.1993. Buku Panduan Teknologi Pangan, Pusat Informasi Wanita dalam Pembangunan PDII-LIPI bekerjasama dengan Swiss Development Cooperation.

Palungkun, R. 2003. Aneka Produk Olahan Kelapa. PEnebar Swadaya. Jakarta

Siahaan, D dan A. Djatmika. 1993. Industri Kelapa Parut Kering dan Hasil Sampingnya. Pusat Penelitian Perkebunan Marihat Bandar Kuala Marihat Olu Pematang Siantar-Sumatera Utara

Wijaya, H. 1982. Pembuatan Kelapa Parut Kering. Buletin Pusbangtepa, 4 (15), Agustus: 21-29.

Witono Y, A. Subagio, W. S. Windrati, Y.Wibowo dan Bambang H.P. 2002. Kajian Teknologi Pembuatan Kelapa Parut Kering yang Bermutu dan Berdaya Simpan Tinggi. Universitas Jember. 